Jahangirnagar University J. Biol. Sci. 6(1): 23-33, 2017 (June)

\title{
Development of an effective in vitro Regeneration protocol for BARI Mash 2 (Vigna mungo L.) an important legume crop in Bangladesh
}

\author{
P. Saha, M. Afrin, A.K.M Mohiuddin ${ }^{1}$ and A.M Shohael* \\ Department of Biotechnology and Genetic Engineering, Jahangirnagar University, Savar, \\ Dhaka 1342, Bangladesh
}

\begin{abstract}
Black Gram (Vigna mungo L.), widely known as Mashkalai in Bangladesh is an important protein source used as human food as well as fodder. BARI Mash 2 is a popular black gram variety released by Bangladesh Agriculture Research Institute (BARI) which is cultivated throughout the country and very popular especially in the char areas. Establishment of a reliable regeneration system for BARI Mash 2 has been tried for further genetic improvement. A rapid, reproducible and efficient in vitro regeneration method was developed using hypocotyl and young leaf explants through callus formation. The frequency of callus formation was highest (75\%) on Murashige and Skoog (MS) medium supplemented with a high concentration $(31.66 \mu \mathrm{M})$ of 2,4-Dichlorophenoxyacetic Acid (2,4-D) using the young leaf as explants' source. Callus induction rate was less in hypocotyls in the same medium. No further progress was observed from those calluses. MS medium containing $16.11 \mu \mathrm{M}$ of $\alpha$ Naphthalene acetic acid (NAA) showed the 70\% calli induction from hypocotyls segment. These calli were amenable to produce multiple shoots (5-6 shoot) in the medium containing $17.75 \mu \mathrm{M}$ of 6 Benzyl aminopurine (BAP) alone and the combination of BAP $(17.75 \mu \mathrm{M})$ and NAA $(2.68 \mu \mathrm{M})$. Shoots were rooted most effectively $(55 \%)$ in half strength MS basal medium containing $7.38 \mu \mathrm{M}$ of Indole-butyric Acid (IBA). Well rooted plantlets were successfully acclimatized, transferred to the soil and found to produce flowers and fruits. The efficient and reproducible regeneration protocol described here allows for successful in vitro regeneration of BARI Mash 2 that is vital for future genetic manipulation.
\end{abstract}

Key words: Callus, Control environment, Growth regulator, Hypocotyls, Indole-butyric Acid (IBA).

\section{INTRODUCTION}

Black gram (Vigna mungo L. Hepper) belonging to the Fabaceae family is an important nitrogen fixing, short-duration, tropical pulse crop commonly grown in semi-arid to sub humid low land tropics and sub tropics including Bangladesh. It is an annual food legume and a day neutral warm season crop with a $\mathrm{pH}$ of 5.5-5.7. It grows in optimum temperature $27-30^{\circ} \mathrm{C}$ and is more water logging tolerant compared to other legume crops (Mony et al., 2010). Black grams are very important food crops for various health benefits (Arnoldi et al., 2014). It has high protein content and the perfect combination of all nutrients, such as proteins (25-26\%), carbohydrates (60\%), fats (1.5\%), minerals,

\footnotetext{
${ }^{1}$ Department of Biotechnology and Genetic Engineering, Mawlana Bhasani Science and Technology University, Tangail-1902, Bangladesh

* Corresponding author Email: amshohael@juniv.edu
} 
amino acids and vitamins (Karamany, 2006). Black grams are extensively cultivated in South Asia especially in India, Bangladesh and now also growing in the Southern parts of United States, West Indies and Japan (Delic et al., 2009). Black gram is used as a demulcent, aphrodisiac and in diabetes, nervous disorders and hair disorders. This crop contains $78 \%$ to $80 \%$ nitrogen in the form of albumin and globulin (Das et al., 2004) and the dry seeds are a good source of phosphorus. It is one of the most important pulses. The dry beans are used as dal. It is also grown as a forage crop (Göhl, 1982).

Black gram is very popular in Bangladesh and ranks third in terms of consumption and four in terms of total areas in which different varieties of legume crops are cultivated. Locally, it is known as 'Mashkalai' or 'Mash' and it is mostly used as a fodder crop for producing high-quality meat and milk (Boelt et al., 2014) and to improve the productivity of livestock by reducing the shortage of fodder in Bangladesh. It is often used as dry season intercrop in rice or wheat as it has a beneficial effect of improving soil nutrient status by providing nitrogen in the soil (Parashar, 2006). It has been reported that the average yield of black gram is about $1000 \mathrm{~kg} \mathrm{ha}^{-1}$ and the protein content is $25-26 \%$ (BINA, 2004). BARI Mash 2 is a popular Mashkalai variety developed by Bangladesh Agriculture Research Institute (BARI) cultivated through the country especially very popular in the char areas as a human food and fodder.

In vitro techniques are able to ease genetic manipulations. The successful application of in vitro methods is greatly dependent on a reliable regeneration system. After the first establishment by Skoog \& Miller (1957) that one of the key variables in the chemical regulation of in vitro organogenesis was the ratio of the auxin-cytokinin present in the medium. Since then, different protocols have been demonstrated for many plant genera through manipulating the auxin cytokinin ratios for the successful regeneration (Koroch et al., 2002). In vitro techniques has been applied for diverse application such as viral elimination, clonal propagation, gene conservation, in vitro fertilization, mutation, induction for genetic diversity, genetic transformation, protoplast isolation and somatic hybridization, secondary metabolite production and other related techniques (Bakrudeen et al., 2013).

Although Black gram is endowed with many good features, the major constraints of its production in Bangladesh are the emergence of new disease and insects, extreme weather condition, soil salinity and less productivity. To overcome those constraints improvement of Black gram is a big challenge. The production of black gram has not improved significantly through conventional breeding due to the lack of related wild species those are resistant against different abiotic and biotic factors. Significant yield losses occurred due to sexual-incompatibility with wild and related species and the reservoir of desirable genes. So, it hardly needs to improve the quality of the legumes in order to get disease free, salt and stress tolerant, toxin free better yield. Development of cell and tissue culture is the prerequisite for gene transformation to develop resistant variety through modern biotechnology. For this the availability of easy, reproducible, reliable and efficient in vitro regeneration protocol is essential. Shoot tip, mature cotyledonary nodes (Goel et al., 1983; Ignacimuthu et al., 1997), immature cotyledonary nodes (Muruganantham et 
al., 2005), and cotyledons (Gill et al., 1987) derived from in vitro raised seedlings have all been used to regenerate black gram shoots in vitro. The morphogenetic responses of cultured cotyledons of $V$. mungo were studied by Gill et al. (1987). Somatic embryo productions by liquid shake culture of embryogenic calluses in V. mungo (L.) were reported (Muruganantham et al., 2010). Successful establishment of in vitro regeneration depends upon two basic factors, such as (1) shoot length of plantlets and root to shoot ratio; and (2) using a potting mix with good aeration and lesser capacity to retain water (Anwar et al., 2011).

Therefore, the present investigation was attempted to develop an efficient and reproducible protocol for successful in vitro regeneration and multiple shoot formation through callus using different explants such as hypocotyls and leaf segments of BARI Mash 2.

\section{MATERIALS AND METHODS}

Plant material: Seeds of BARI Mash 2 for this study were collected from Bangladesh Agricultural Research Institute (BARI) through the courtesy of Bangladesh Livestock Research Institute (BLRI). Young leaves and hypocotyl were used as explants' source from in vitro grown seedlings.

In vitro seed germination: The seeds of BARI Mash 2 were surface sterilized with $70 \%$ ethanol (v/v) for 2 min followed by washing twice with sterilized distilled water for 4 times. For in vitro germination the surface of BARI Mash 2 seeds were sterilized using different concentration and incubation time on commercial Clorox (1\% Sodium Hypochlorite) and Tween 20. Seeds were treated with 10, 20, 30, 40, 50, 60, 70 and 80\% of commercial bleach Clorox (1\% Sodium Hypochlorite) and incubated for 15- 45 mins. Few drops of Tween 20 were added to enhance the effect of Clorox. The seeds were then rinsed 3-4 times with sterile distilled water to remove all of the Clorox. After that, the seeds were placed in sterilized tissue paper with the help of forceps to remove excess water before inoculation in the medium. The sterilized seeds were placed on a solidified agar medium containing no growth regulators in sterile jars and incubated in the dark room for germination. The sterilized seeds were germinated in the dark room within 2-3 days and reached up to 7-8 $\mathrm{cm}$ long within 5-6 days. Young leaves and hypocotyls segment were ready for further experiments.

Nutrient medium and growth regulators: Murashige and Skoog (MS) medium (Murashige \& Skoog, 1962) was used for callus induction and plant regeneration. For the induction of callus, different concentrations $(0.0,2.26 \mu \mathrm{M}, 4.52 \mu \mathrm{M}, 9.04 \mu \mathrm{M}$, $13.57 \mu \mathrm{M}, 18.10 \mu \mathrm{M}, 22.62 \mu \mathrm{M}, 27.14 \mu \mathrm{M}, 31.66 \mu \mathrm{M}$ and $36.19 \mu \mathrm{M})$ of 2, 4Dichlorophenoxyacetic Acid (2, 4-D) and $(0.0,2.68 \mu \mathrm{M}, 5.37 \mu \mathrm{M}, 10.74 \mu \mathrm{M}, 16.11$ $\mu \mathrm{M}, 21.48 \mu \mathrm{M}$ ) Naphthalene Acetic Acid (NAA) alone were used. 6-Benzyl Aminopurine (BAP) alone (0.0, $4.44 \mu \mathrm{M}, 8.88 \mu \mathrm{M}, 13.31 \mu \mathrm{M}, 17.75 \mu \mathrm{M}$, and $22.20 \mu \mathrm{M}$ ) and different combinations of BAP and NAA $(13.31 \mu \mathrm{M},+1.34 \mu \mathrm{M}, 13.31 \mu \mathrm{M}+2.68$ $\mu \mathrm{M}, 13.31 \mu \mathrm{M}+5.37 \mu \mathrm{M}, 17.75 \mu \mathrm{M}+1.34 \mu \mathrm{M}, 17.75 \mu \mathrm{M}+2.68 \mu \mathrm{M}, 17.75 \mu \mathrm{M}+5.37)$ 
were added to the MS medium for shoot initiation and plant regeneration. For root induction different concentrations $(2.46 \mu \mathrm{M}, 4.92 \mu \mathrm{M}, 7.38 \mu \mathrm{M}$ and $9.84 \mu \mathrm{M})$ of Indole Butyric Acid (IBA) and $(1.34 \mu \mathrm{M}, 2.68 \mu \mathrm{M}, 5.37 \mu \mathrm{M})$ NAA were added in to the $1 / 2$ strength of MS medium.

Media sterilization and culture condition: All the culture media were sterilized in an autoclave machine at $121^{\circ} \mathrm{C}$ for 20 minutes at $15 \mathrm{psi}$. The explants were cultured in each media combination under aseptic conditions and incubated at $24 \pm 1^{\circ} \mathrm{C}$ under dark conditions for germination and 16/8h light/dark regime for callus initiation and plant regeneration.

Callus induction and regeneration: For callus induction, young leaves and hypocotyl were collected from 5-6 days old in vitro grown seedlings. In the laminar hood leaves and hypocotyl were cut into small pieces $(1.0 \mathrm{~cm})$ in a sterile glass Petri dish and placed into the other Petri dish with sterile distilled water, not for drying. After that small pieces were placed into the appropriate semi solid medium into the glass jar having different concentration of growth regulators. 4-6 explants were placed in one jar and sealed properly before inoculation in the growth chamber.

Rooting and Acclimatization: Regenerated shoots were separated and sub cultured into the half strength of fresh MS medium with rooting hormone and incubated further for rooting. Well rooted plants were selected and taken out from the glass jar, washed with running tap water to remove the agar in the roots and planted in sterile soil mix and kept in a humid chamber for acclimation.

Data recording: Data were recorded for callus induction and growth in the different time period and observed the callusing responses daily. Shoot regeneration data was recorded after five weeks of culture in regeneration medium. Data for root initiation was taken after 28 days of culture.

Statistical Analysis: The data collected in different parameters like callus initiation, callus frequency, regeneration percentage, the number of shoots per callus, percentage of root initiation were calculated on the basis of percentage, average, and standard deviation respectively.

\section{RESULTS AND DISCUSSION}

Seed sterilization and germination: In this study, 50\% Chlorox with 5 drops of Tween 20 and 30 minutes of incubation period with vigorously shaking was found optimum for seed sterilization without killing or contamination (data not shown).

Callus induction: In this experiment, hypocotyl and leaf segments were chosen as explants for callus initiation. Explants were cultured on MS medium containing different concentrations of Auxin (2,4-D and NAA) to identify and select the optimum amount of growth regulators for maximum callus initiation and shoots regeneration. Effect of auxins 
on callus formation is presented in Table 1. For callus induction, nine different concentrations of 2,4-D were used in this experiment to observe the callus induction efficiency from two different explants (hypocotyl and leaf) of BARI Mash 2. In our experiment, it was observed that callus formation was highly affected by 2,4-D concentration in different explants and increase the level of 2,4-D accelerated the callus initiation in short period of time. Maximum $75 \%$ of callus induction was observed within 12-15 days in leaf segments where MS medium was supplemented with $31.66 \mu \mathrm{M}$ 2,4-D and lowest $38 \%$ of callus induction was achieved within 18-22 days when MS medium was supplemented with $2.26 \mu \mathrm{M} 2$, 4-D in the same explants (Table 1). The texture of the callus was mostly compact and green when the hormonal concentrations were low and friable green callus at higher concentrations (Fig. 3B). The leaf explants showed better callus initiation than hypocotyl explants (Fig. 1). Though the 2,4-D concentration was effective for callus induction in short time the calli were failed to further proliferation and regeneration. After 2 or 3 sub cultures these calli become necrotic and died. It was presumed that highly compact calli were failed to further proliferation. Another type of auxin NAA was also used in different concentrations in two explants to compare the viability of callusing responses. It was observed that for callus initiation 13-21 days necessary in MS medium containing NAA concentrations (Table 1). The growth of callus induced from leaf explants was poor compared to the callus induced from hypocotyl (Table 1). Culture medium without any growth regulators (control) did not show any positive response towards callus induction. It was reported by Geetha et al. (1998) that response of shoot tips for the callus development was better than other explants. In our experiment leaf segment responded better for callus formation (Fig. 1). This difference might be due to the variation of genotype.

Table 1. Effect of different concentrations of Auxin (2,4-D and NAA) in MS medium for callus induction from different explants of BARI Mash 2

\begin{tabular}{|c|c|c|c|c|c|}
\hline \multirow{2}{*}{\multicolumn{2}{|c|}{$\begin{array}{l}\text { Concentrations of plant } \\
\text { growth regulators }(\mu \mathrm{M})\end{array}$}} & \multirow{2}{*}{$\begin{array}{c}\text { Callus } \\
\text { initiation } \\
\text { time (Days) }\end{array}$} & \multicolumn{2}{|c|}{ Degree of callus } & \multirow{2}{*}{$\begin{array}{c}\text { Callus } \\
\text { Induction } \%\end{array}$} \\
\hline & & & Leaf & Hypocotyls & \\
\hline \multirow{10}{*}{$2,4-\mathrm{D}$} & 0.00 & - & - & - & - \\
\hline & 2.26 & $18-22$ & + & + & 38 \\
\hline & 4.52 & $17-21$ & ++ & ++ & 40 \\
\hline & 9.04 & $15-20$ & ++ & ++ & 45 \\
\hline & 13.57 & $15-20$ & ++ & +++ & 48 \\
\hline & 18.10 & $13-18$ & ++ & +++ & 50 \\
\hline & 22.62 & $12-16$ & ++ & + & 55 \\
\hline & 27.14 & $13-16$ & +++ & + & 60 \\
\hline & 31.66 & $12-15$ & +++ & + & 75 \\
\hline & 36.19 & $11-14$ & ++ & + & 64 \\
\hline \multirow{6}{*}{ NAA } & 0.00 & - & - & - & - \\
\hline & 2.68 & $18-20$ & - & + & 53 \\
\hline & 5.37 & $16-21$ & + & ++ & 60 \\
\hline & 10.74 & $15-18$ & + & ++ & 65 \\
\hline & 16.11 & $13-16$ & + & +++ & 70 \\
\hline & 21.48 & $12-15$ & + & +++ & 62 \\
\hline
\end{tabular}




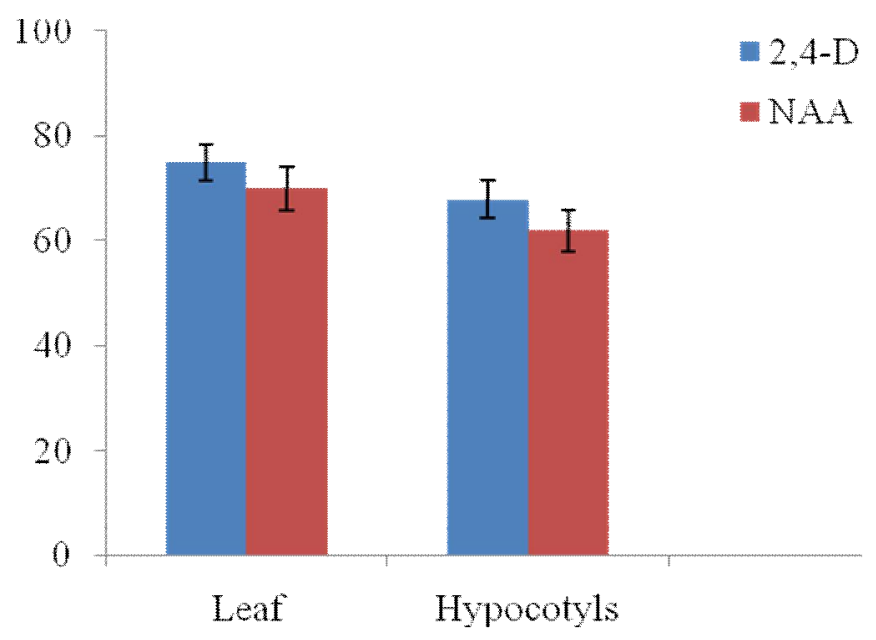

Fig. 1. Effect of Auxin on callusing response in two different explants (leaf segments and hypocotyls) of BARI Mash 2

Shoot regeneration: Effect of cytokinin (BAP) was also tested for callus induction and shoot regeneration in this experiment. The nature of callus was found soft and friable (Fig. 2C) after 12-18 days. After 4-5 weeks regeneration of shoots was started from the induced callus. Maximum $60 \%$ of callus produced shoots in MS medium containing $17.75 \mu \mathrm{M}$ of BAP (Table 2), the highest number of shoots per callus was recorded to be 56 and shoot length reached up to $1.48 \mathrm{~cm}$ (Fig. 2E and Fig. 2F). It was reported that BAP was proved to be an ideal hormone for shoot multiplication of hypocotyl culture in grain legumes. Hypocotyl explants showed better callus formation response than the leaf in different BAP concentration (Adlinge et al., 2014). In vitro regeneration through multiple shoots development of black gram has also been reported by using various explants by different scientists (Geetha et al., 1998, Muruganantham et al., 2005).

It was reported that the efficiency of multiple shoot formation is dependent on various parameters. Among them, size, age and type of explant, genotype, media composition, and growth regulators are most important (Jaiwal \& Gutali, 1995; Saini et al., 2004). For in vitro regeneration of black gram various explants, stem, epicotyl, cotyledonary node, excised cotyledons, hypocotyl segments, cotyledons and embryo axes, cotyledons attached to de-apexed embryo axes, embryo axes and shoot tips (Gill et al., 1987, Sen \& Guha, 1998, Ignacimuthu \& Franklin, 1999, Agnihotri et al., 2001) were found suitable.

Application of specific hormones at the desired level and successive subculture enhances the callus regeneration from different explants. In our experiment, multiple shoots (Fig. 2) were observed in the presence of different concentrations of BAP alone and in the combination of BAP and NAA. A good number of multiple shoots were observed at $17.75 \mu \mathrm{M}$ BAP via callus formation. The number of shoots was increased after the second subculture. The total 1-2 shoot was obtained in the low concentration of BAP and 
the average shoot length was highest (Table 2). Different combinations of BAP combined with NAA were also used in regeneration medium. It is clear that the response was lower when two hormones were used together rather than BAP alone. But at high BAP and low NAA concentration, the highest percentage of shoots was obtained. Result obtained from this experiment is shown in Table 2. A positive effect of low concentration of cytokinin on multiple shoot regeneration was also observed in other legume, such as V. raditata (Chandra \& Pal, 1995; cowpea (V. unguiculata Muthukumar et al., 1996), chickpea (Cicer aritenum) (Chakraborti et al., 2006; Das et al., 2016) grass pea (Lathyrus sativus) (Saha et al., 2015), black gram (Periyakaruppiah et al., 2016).

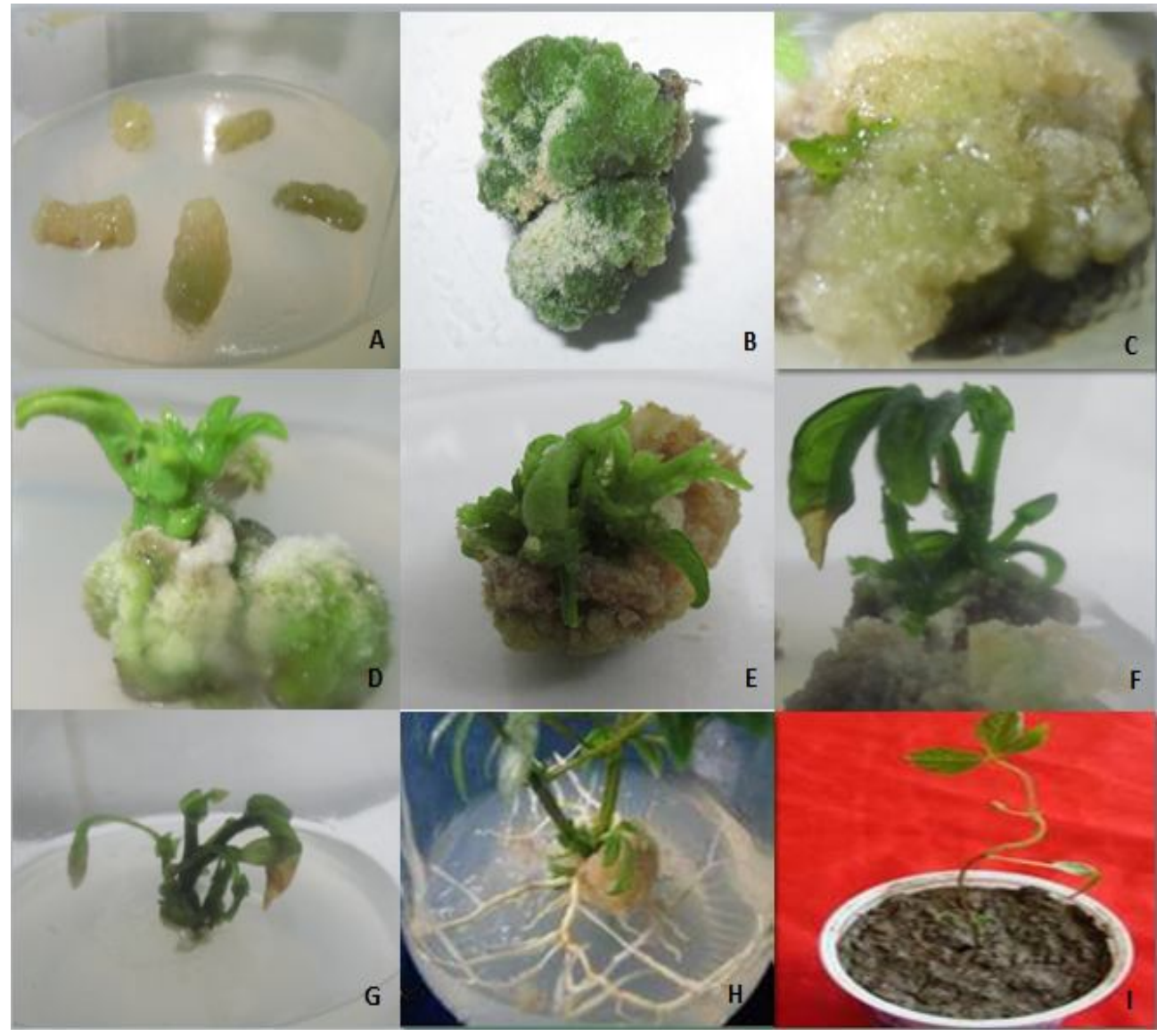

Fig. 2. Shoot organogenesis from cotyledonary node explants of BARI Mash 2, A) Callus initiation after seven days of incubation, B) Callus after one month of initiation, C-F) Multiple shooting, G) Shoot on root medium, H) Shoot forming roots and I) Acclimatized plant in the soil 
Table 2. Effects of Cytokinin (BAP) and the combination of Auxin (NAA) and Cytokinin (BAP) in MS medium on shoot regeneration from hypocotyls explants of BARI Mash 2

\begin{tabular}{|c|c|c|c|c|c|c|}
\hline \multicolumn{2}{|c|}{$\begin{array}{l}\text { Concentrations of plant } \\
\text { growth regulators }(\mu \mathrm{M})\end{array}$} & $\begin{array}{c}\text { Days to } \\
\text { callus } \\
\text { initiation }\end{array}$ & $\begin{array}{l}\text { Days to shoot } \\
\text { initiation from } \\
\text { callus on same } \\
\text { medium }\end{array}$ & $\begin{array}{l}\% \text { of shoot } \\
\text { regeneration }\end{array}$ & $\begin{array}{l}\text { Number } \\
\text { of shoot } \\
\text { per callus }\end{array}$ & $\begin{array}{l}\text { Shoot } \\
\text { length } \\
(\mathrm{cm})\end{array}$ \\
\hline \multirow{6}{*}{ BAP } & 0.00 & NR & NR & NR & NR & $\mathrm{NR}^{*}$ \\
\hline & 4.44 & 15 & 25 & 40 & $1-2$ & 2.51 \\
\hline & 8.88 & 16 & 26 & 45 & $2-3$ & 2.13 \\
\hline & 13.31 & 17 & 28 & 57 & $2-4$ & 1.92 \\
\hline & 17.75 & 18 & 30 & 60 & $5-6$ & 1.48 \\
\hline & 22.20 & 20 & 36 & 54 & $3-4$ & 1.28 \\
\hline \multirow{6}{*}{$\mathrm{BAP}+\mathrm{NAA}$} & $13.31+1.34$ & 18 & 28 & 25 & $1-2$ & 0.78 \\
\hline & $13.31+2.68$ & 17 & 30 & 28 & $1-2$ & 1.00 \\
\hline & $13.31+5.37$ & 16 & 32 & 34 & $2-3$ & 1.12 \\
\hline & $17.75+1.34$ & 15 & 32 & 39 & $2-3$ & 1.23 \\
\hline & $17.75+2.68$ & 13 & 30 & 45 & $2-3$ & 1.38 \\
\hline & $17.75+5.37$ & 12 & 30 & 30 & $2-3$ & 1.25 \\
\hline
\end{tabular}

${ }^{*}$ NR- No response

Root induction: The rooting of shoots was significantly affected by the auxin concentration (Table 3). MS medium strength has a clear effect on root induction from the regenerated shoots. Half strength MS medium supplemented with $7.38 \mu \mathrm{M}$ IBA and $5.37 \mu \mathrm{M}$ NAA performed better and required the least number of days for rooting (Fig. $2 \mathrm{H})$. A higher percentage of rooting $(55 \%)$ was found with $7.38 \mu \mathrm{M} \mathrm{IBA}$ in the present study (Table 3).

Table 3. Effect of different concentrations of IBA and NAA in half strength of MS medium on root induction from in vitro grown shoots of BARI Mash 2

\begin{tabular}{cccc}
\hline $\begin{array}{c}\text { Concentrations of plant } \\
\text { growth regulators }(\mu \mathrm{M})\end{array}$ & Root induction $\%$ & $\begin{array}{c}\text { Number of roots obtained per } \\
\text { shoot }\end{array}$ \\
\hline \multirow{4}{*}{ IBA } & 0.00 & No Response & No Response \\
& 2.46 & 35 & 2 \\
& 4.92 & 46 & 4 \\
& 7.38 & 55 & 6 \\
\hline \multirow{2}{*}{ NAA } & 9.84 & 53 & 5 \\
& 0.00 & No Response & No Response \\
& 1.34 & 35 & 3 \\
& 2.68 & 42 & 4 \\
\hline
\end{tabular}

Transplantation in Soil: Tissue culture jar having the well rooted mini plantlets were slightly open for 24 hours in the growth chamber to exchange fresh air then carefully moved washed the roots with distilled water and kept in the moist tissue paper before transplanted. Further, the plantlets were planted in the small earthen pot containing sterilized soil and compost mix and kept in the small plastic covering for 12-14 days. The relative humidity was maintained about $75 \%$ by frequently spraying the water inside for 
hardening. After 2 weeks, the hardened plantlets were transferred to the soil under the shade and watered every day (Fig 2I). Finally, the survived plantlets were grown normally in the garden produced flowers and fruits.

Several attempts were taken to enhance the black gram tolerant against different abiotic and biotic stresses through classical breeding with very limited success. However, breeding of black gram is difficult due to the fact that it is self-pollinating crop and the genetic variation among its varieties is narrow. So there is an urgent need to use transgenic approach for the improvement of black gram. Grain legumes are comparatively recalcitrant to regeneration and transformation. In grain legumes, tissue culture has been repeatedly described as difficult. In our experiment, an efficient regeneration protocol was successfully established for in vitro culture of BARI Mash 2, which will be useful in future genetic improvement of plants through biotechnology and genetic engineering. This will definitely help in developing novel cultivars suitable for growth in different stress affected areas in Bangladesh.

Acknowledgements: The authors gratefully acknowledged the financial support provided by Jahangirnagar University and UGC research grant. Authors are also thankful to Dr. Nathu Ram Sarker of Fodder Improvement project in Bangladesh Live Stock research Institute for providing us the seeds of BARI Mash 2.

\section{REFERENCES}

Adlinge, P.M. Samal, K.C., Kumara Swamy, R.V. and Rout, G.R. 2014. Rapid in vitro Plant Regeneration of Black Gram (Vigna mungo L. Hepper) Var.Sarala, an Important Legume Crop. Proc. Natl. Acad. Sci., India Section. B: Biological Sciences. 84: 823-827.

Agnihotri, S., Singh R.R. and Chaturvedi H.C. 2001. In vitro high frequency regeneration of plantlets of Vigna mungo and their ex vitro growth. Ind. J. Exp. Biol. 39: 916-920.

Anwar, F., Alghamdi, S.S., Ammar M.H. and Siddique, K.M.H. 2011. An efficient in vitro regeneration protocol for faba bean (Vicia faba L.). Jour. of Med. Plant. Res. 5: 64606467.

Arnoldi, A., Zanoni, C., Lammi, C., and Boschin, G. 2014. The role of grain legumes in the prevention of hypercholesterolemia and hypertension. Crit. Rev. Plant Sci. 33. 1-3.

Boelt, B., Julier, B., Karagic, D., and Hampton, J. 2014. Legume seed production meeting market requirements and economic impacts. Crit. Rev. Plant Sci. 33: 116-122.

Bakrudeen A. A. A., Mohajer, S., Elnaiem, E.M. and Taha, R.M. 2013. In vitro Regeneration and Somatic Embryogenesis and their Antimicrobial studies in selected Ornamental plants, Editors (Nabin Kumar Dhal and Sudarn Charan Sahu, In Tech, Plant Science, ISBN 980953-307-033-4, Chapter -11, Pp: 255-274.

Chakraborti, D., Sarkar, A. and Das, S. 2006. Efficient and rapid in vitro plant regeneration system for Indian cultivars of chickpea (Cicer arietinum L.). Plant Cell Tiss. Org. Cult. 86: 101105 .

Chandra, M. and Pal, A. 1995. Differential response of the two cotyledons of Vigna radiate. In vitro Plant Cell Rep. 15: 248-253.

Das, D.K., Bhagat, M. and Shree, S. 2016. Agrobacterium mediated transformation of Vigna mungo L. Hepper with Cry1Ac gene for insect resistance. American J. of Plant Sci. 7: 316-325. 
Das, D.K., Shivaprakash, N. and Sarin, N.B. 2004. An efficient regeneration system of blackgram (Vigna mungo L.) through organogenesis. Plant Sci. 134: 199-206.

Delic, D., Stajkovic, O., Kyzmanovic, D., Rasulic, N., Knezevic, S. and Milicic, B. 2009. The effects of rhizobial inoculation on growth and yield of Vigna mungo L. in Serbian soils. Biotechnol. Anim. Husb. 25: 1197-1202.

Geetha, N., Venkatachalam, P. and Rao, G.R. 1998. In vitro plant regeneration from shoot tip culture of black gram (Vigna mungo L. Hepper). J. Tropic. Agric. 36:6-11.

Gill, R., Eapen, S. and Rao, P.S. 1987. Morphogenic studies of cultured cotyledons of urd bean(Vigna mungo L. Hepper). J. Plant. Physiol. 139: 1-5.

Göhl, B. 1982. Les aliments du bétail sous les tropiques. FAO, Division de Production et Santé Animale, Roma, Italy.

Goel, S., Mudgal, A.K. and Gupta S.C. 1983. Development of plants from in vitro cultured shoottips of Vigna mungo and Vigna radiata. Trop. Plant Sci. Res. 1: 31-33.

Ignacimuthu, S. and Franklin, G. 1999. Regeneration of plantlets from cotyledon and embryogenic axis explants of Vigna mungo L. Hepper. Plant Cell Tiss. Org. Cult. 55:75-78.

Ignacimuthu, S., Franklin, G. and Melchias, G. 1997. Multiple shoot formation and in vitro fruiting of Vigna mungo L. Hepper. Curr Sci. 73: 733-735.

Jaiwal, P.K. and Gulati, A. 1995. Current status and future strategies of in vitro culture techniques for genetic improvement of mungbean (Vigna radiata L.) Wilczek. Euphytica 86: 167181 .

Karamany, E.L. 2006. Double purpose (forage and seed) of mungbean production 1-effect of plant ensity and forage cutting date on forage and seed yields of mungbean (Vigna radiata L. Wilczeck) Res. J. Agric. Biol. Sci. 2:162-165.

Koroch, A., Juliani, H.R. Kapteyn, J. and Simon, J.E. 2002. In vitro regeneration of Echinacea purpurea from leaf explants. Plant Cell Tiss. and Org. Cult. 69: 79-83.

Mony, S.A., Haque M.S., Alam, M.M., Hasanuzzaman, M. and Nahar, K. 2010. Regeneration of black gram (Vigna mungo L.) on changes of hormonal condition. Not. Bot. Hort. Agrobot. Cluji. 38: 140-145.

Murashige, T. and Skoog, F. 1962. A revised medium for rapid growth and bio-assays with tobacco tissue culture. Plant Physiol. 15: 473-497.

Muruganantham, M., Ganapathi, A., Amutha, S., Vengadesan, G. and Selvaraj, N. 2005. Shoot regeneration from immature cotyledonary nodes in black gram (Vigna mungo L. Hepper). Indian J. Biotechnol. 4: 551-555.

Muruganantham, M., Amutha, S. and Ganapathi, A. 2010. Somatic embryo productions by liquid shake culture of embryogenic calluses in Vigna mungo (L.) Hepper. In vitro Cell. Dev. Biol. Plant. 46: 34-40.

Muthukumar, B., Mariamma, M., Veluthambi, K. and Gnanam, A. 1996. Genetic transformation of cotyledon explants of cowpea (Vigna unguiculata L. Walp) using Agrobacterium tumefaciens. Plant Cell Rep. 15: 980-985.

Parashar, S.M.P. 2006. Post harvest profile of black gram. MRPC-71, Ministry of agriculture, Directorate of marketing and inspection, India

Periyakaruppiah, P., Eyini , M., Rajarathinam, K. and Jayakumar, M. 2016. Effect of UV-B (280$320 \mathrm{~nm}$ radiation in IN-VITRO culture from callus explants of black gram cultivars. Int. J. of Curr. Sci. Res. 2: 2454-5422.

Saha, P., Afrin, M., Mohiuddin, A.K.M. and Shohael, A.M. 2015. In vitro regeneration of grass pea (Lathyrus sativus L.). Jahangirnagar University J. Biol. Sci. 42: 1-8.

Saini, R., Sonia, M.S., Badola, A. and Jai-wal, P. K. 2004. An improved protocol for plant regeneration via somatic embryogenesis from cell suspension cultures of Vigna mungo L. Hepper. Physiol. Mol. Biol. Plants. 10: 121-125. 
Sen, J. and Guha, M.S. 1998. In vitro induction of multiple shoots and Plant regeneration of Vigna mungo. In vitro Cell. Dev. Biol. Plant. 34: 276-280.

Skoog, F. and Miller, C.O. 1957. Chemical regulation of growth and organ formation in plant tissue cultures in vitro. Symp. Soc. Exp. Biol. 11: 118-131. 